\title{
The impacts of light rail on residential property values in a non- zoning city: A new test on the Houston METRORail transit line
}

\author{
Qisheng Pan \\ Tongji University \\ Texas Southern University \\ pan_qs@tsu.edu
}

Abstract: The impacts of rail transit system on residential property values have been examined for many metropolitan areas in the U.S. But there are few studies on the effects of light rail in a non-zoning city. As the rail transit in the largest non-zoning city, Houston's light rail transit line, or the so-called METRORail, has not received much attention from the planning research society since it opened to the public in 2004. A previous study by the author utilized 2007 household data to analyze the impacts of Houston's METRORail line and found the net effects of the rail transit line change significantly at different distances from the rail stations. One limitation of that study was that the physical environment and neighborhood characteristics of the station areas may not have had notable changes over a relatively short time span, i.e., three years after the opening of the light rail. This study employs 2010 InfoUSA household data to re-examine the effects of Houston's METRORail line. Similar to the previous studies, the author adopts a traditional ordinary linear regression (OLS) to investigate the contribution of a set of variables representing the physical, neighborhood, and accessibility characteristics of properties, and also employs a multi-level regression model (MLR) to examine the hierarchical structures of spatial data explicitly. In addition, this study tests the spatial autocorrelation in the modeling process and analyzes its effects on the results. The modeling results suggest that the METRORail line has had significant net positive effects on residential property values. The MLS model captures the difference of these effects with more spatial details. The spatial regression model improves model fit, but spatial autocorrelation is not completely eliminated.

Keywords: Light rail, residential property values, soning, ordinary linear regression, multi-level regression model, METRORail.

\section{Article history:}

Received: September 17, 2017

Received in revised form:

December 8, 2018

Accepted: January 6, 2019

Available online: April 15, 2019

\section{Introduction}

There are a large number of studies on the impact of rail transit services in many cities However, few of them have been conducted for a non-zoning city. Zoning has been a common method of controlling land use in U.S. cities since the 1920s. It is important for decision makers and planning scholars to

Copyright 2019 Qisheng Pan

http://dx.doi.org/10.5198/jtlu.2019.1310

ISSN: $1938-7849$ | Licensed under the Creative Commons Attribution - Noncommercial License 4.0

The Journal of Transport and Land Use is the official journal of the World Society for Transport and Land Use (WSTLUR) and is published and sponsored by the University of Minnesota Center for Transportation Studies. 
understand the effects of zoning on land use and urban development. It is also interesting for them to learn the effects of rail transit services in a non-zoning city, which may or may not be similar to those in a zoning city.

An intuitive assumption is that a non-zoning city may have a land-use pattern significantly different from a zoning city. The land-use decisions in a non-zoning city are considered to be more efficient from the perspectives of individual landowners. But these private efficiencies may be offset by the negative external effects associated with unregulated land-use patterns (Ottensmann, 1998). Therefore, a non-zoning city may have lower job density, more diversity, and less effective agglomeration economies than those in a zoning city (Liu, Pan, King, \& Jin, 2018). It is possible that the dissimilar land-use policies in these two types of cities affect residential and business location decisions differently, which may make their rail transit services have the disparate effects on residential property values.

Traditional zoning regulations or ordinances were expected to be effective in controlling negative externalities and upholding residential property values. But some studies reported no evidence of the effects of zoning on the density of development, the residential land-use patterns, and the market values of residential properties (Jud, 1980). Due to doubts about the positive effects of zoning and the concerns over its possible drawbacks, Houstonian voted down the proposals to implement conventional zoning in the city multiple times. The last proposal in 1993 was favored by middle income white and African American but opposed by all the other ethnic and income groups (McDonald, 1995).

As the largest non-zoning city in the U.S., Houston has its unique features that are different from many other large cities. Instead of zoning regulations, home owner associations control land uses through voluntary agreements as restrictive covenants or deed restrictions, sometimes which are more restricted than zoning ordinances in certain areas (Siegan, 1972). Houston is also known for pro-growth, low taxes, and anti-regulation. Houstonian mostly adhere to the liberal mind view government should not interfere in commercial affairs because markets work better in guiding land-use control and commercial development (TRB, 1996).

Houston's land development also has the characteristic of leapfrogging, accounting for a large amount of vacant land (Mieszkowski \& Mills, 1991). The City of Houston's average population density was a low 5.27 people per acre in 2000, which is much lower than the population density of 31 people per hectare (or 76.57 people per acre) to support a mass transit system (Bertaud, 2003).

Transit service in Houston has been limited to its core county, i.e., Harris County. According to the ATPA 2011 fact book, total light rail passenger trips are 11,613.7 thousand and passenger miles are 27,501.4 thousand, which makes Houston rank 13th and 18th among the U.S. light rail transit agencies, respectively (ATPA, 2011). Table 1 shows the transit mode share of trips to work in Houston increased from 2.9 percent to 3.7 percent between 1980 and 1990 but dropped to 3.3 percent in 2000 while the drove-alone steadily increased from 69.4 percent to 76.1 percent between 1980 and 1990 and further increased to 77 percent in 2000. The transit mode share of trips to work in Houston further decreased to 2.2 percent while the drove-alone increased to 78.8 in 2009 according to the 2009 American Community Survey. 
Table 1. Mode shares of commuting trips in Houston Metropolitan Statistical Area, 1980-2009

\begin{tabular}{|l|r|r|r|r|r|r|r|}
\hline & \multicolumn{4}{|c|}{ Houston } & \multicolumn{3}{c|}{ Large US Metro Areas*1 $^{*}$} \\
\hline Mode & 1980 & 1990 & 2000 & $2009^{* 2}$ & 1980 & 1990 & 2000 \\
\hline Drove Alone & 69.4 & 76.1 & 77 & 78.8 & 65.07 & 72.21 & 73.71 \\
\hline Carpool & 22.5 & 14.6 & 14.2 & 12.1 & 18.72 & 13.40 & 12.64 \\
\hline Transit & 2.9 & 3.7 & 3.3 & 2.2 & 8.54 & 6.92 & 6.43 \\
\hline Walk & 2.7 & 2.3 & 1.6 & 1.6 & 4.50 & 3.39 & 2.69 \\
\hline Others & 2.5 & 3.3 & 3.9 & 5.3 & 3.16 & 4.07 & 4.53 \\
\hline Total Workers (1000) & 1,512 & 1,769 & 2,082 & 2,709 & 27,981 & 34,744 & 38,009 \\
\hline Total Population (1000) & 3,120 & 3,731 & 4,670 & 5,867 & 62,101 & 71,417 & 82,329 \\
\hline
\end{tabular}

Notes: 1. Large US metro areas have population greater than 3 million in 2000 excluding New York. Source: Census Transportation Planning Package (CTPP), 1980-2000 data sets.

2. 2009 data are obtained from the 2009 American Community Survey.

Due to the decentralization trend (often simplified via the catch phrase "urban sprawl"), Houston's population density is low, suggesting that it is not feasible to support a sustainable public transit system to operate in the entire metropolitan area. Transit service in Houston has been mainly limited to the core county, Harris County. Similar to the other comparable cities, Houston has a low and continually decreasing transit mode share. All the evidence makes it a reasonable expectation that Houston's METRORail has little, if any, effect on residential property values. However, most discussions on the relationship between density and transit system ignore the variation of density within a metropolitan area (Bertaud, 2003, 2004). Many studies do not provide details on spatial variation of transit mode share in large metropolitan areas. It is possible that the light rail in Houston has significant effects on land-use change and residential property values in the light rail corridor due to the relatively high transit mode share in the corridor and its unique land-use policies. Table 1, for example, does not provide sufficient details on spatial variation of transit mode share in Houston, especially for commuting trips to Downtown Houston. A commute survey in 2009 showed a surprisingly high public transit mode share in downtown Houston (Table 2). Therefore, it is important to incorporate spatial variation into the analysis.

Table 2. Mode share of downtown Houston commuting, 2009

\begin{tabular}{|l|r|r|}
\hline Mode & Number of Respondents & Mode Share \\
\hline Drive alone & 5,977 & $48.40 \%$ \\
\hline Carpool & 1,377 & $11.15 \%$ \\
\hline Vanpool & 180 & $1.46 \%$ \\
\hline Park \& Ride & 3,558 & $28.81 \%$ \\
\hline Local or express bus & 489 & $3.96 \%$ \\
\hline Light rail & 153 & $1.24 \%$ \\
\hline Bus and rail & 328 & $2.66 \%$ \\
\hline Walk & 129 & $1.04 \%$ \\
\hline Rarely travel to downtown & 66 & $0.53 \%$ \\
\hline Motorcycle or scooter & 55 & $0.45 \%$ \\
\hline Bicycle & 38 & $0.31 \%$ \\
\hline Sum & 12,350 & $100.00 \%$ \\
\hline
\end{tabular}


The effects of Houston's METRORail on residential property values were examined in very few studies. The empirical analyses by Pan and Ma (2009) and Pan (2013) employed both a Hedonic Price Model (HPM) with Ordinary Least Square (OLS) function and a multilevel regression (MLR) model to examine the impacts of Houston's light rail system. It obtained information on home sales prices and physical characteristics of properties from InfoUSA's 2007 household database. They reported that the opening of the light rail has had significant net positive effects on residential property values. But immediate proximity to light rail stations and bus stops had significant negative impacts on properties located within a quarter mile of rail stops. One limitation of this study was that the data collected in a relatively short time span, i.e., three years after the opening of the light rail, may not capture the changes of physical environment and neighborhood characteristics of the station areas, which usually take a long time to mature.

An interesting comparison between the METRORail in Houston, Texas, with the Metro lines in Shanghai also showed that both rail transit systems had significantly positive effects on residential property values, but notable variations of their effects were observed at different distance ranges and time spans in Houston and Shanghai (Pan, Pan, Zhang, \& Zhong, 2014).

The HPM model with the cross-sectional data is the most common methodology in the literature for estimating the implicit value of differences in property characteristics (Debrezion, Pels, \& Rietveld, 2007; Dubé, Thériault, \& Des Rosiers, 2013). However, the inherent spatial nature of this approach may lead to spatial dependence and heterogeneity. Spatial dependence or spatial autocorrelation results from spatial correlation among observations that are assumed to be independent, while spatial heterogeneity comes from the spatial correlation of the error terms (Anselin, 1988). As Higgins and Kanaroglou (2016) pointed out, it is important to take into account the spatial dependence and heterogeneity in examining the effects of rail transit since the failure to address this issue may lead to the violation of the statistical independence assumption, heteroskedasticity, biased estimates, and unreliable test statistics, etc.

Moran's I statistics and Lagrange multiplier tests have been usually employed to examine the presence of spatial dependence and heterogeneity. Spatial methods such as spatial lag models and spatial error models have been adopted to control spatial dependence and heterogeneity. Spatial fixed effects have been used to capture spatial dependence and heterogeneity. Geographically Weighted Regression (GWR) has been developed to explore spatial varying relationship and examine heterogeneity between dependent and independent variables over space. The difference-in-differences (DID) estimator provides a means for avoiding the bias due to omitted variables. But all these methods have advantages and drawbacks linked to their uses (Higgins \& Kanaroglou, 2016).

The objective of this study is to conduct a new test on the Houston METRORail Transit Line to identify impacts on residential property values by controlling spatial dependence and heterogeneity. To compare with the previous studies, the author also adopts a traditional ordinary linear regression (OLS) using recent property transaction data to investigate the contribution of a set of variables representing the physical, neighborhood, and accessibility characteristics of properties, and also employs a multi-level regression model (MLR) to examine the hierarchical structures of spatial data explicitly. In addition, this study tests spatial dependence and heterogeneity in the modeling process using Moran's I statistics and control the spatial dependence and heterogeneity of the variables using spatial regression models.

In subsequent sections, we review the relevant literature in Section 2, describe the methodology in Section 3, present the empirical study in Section 4, and summarize findings and draw conclusions in Section 5 . 


\section{$2 \quad$ Literature review}

More than 20 cities across the US have built new light rail systems or extended existing lines since 1990 (Ransom, 2018). In urban economics, the improvement of transportation infrastructure like rail transit systems and the change of accessibility to job and other opportunities are expected to alter the location choices of households and firms and also affect property values.

An early land-use theory by von Thünen (1826) explained the variations of farmland values and pointed out that agricultural land-use distribution and land prices are a function of the accessibility to the market. As descendants of von Thunen's model, the bid rent functions by Alonso (1964), Mills (1967), and Muth (1969) assumed that households choose optimal locations by trading off transportation costs and other household consumptions, which yields a land rent gradient declining with distance from the central business district (CBD). As the center of many opportunities, especially the location with the highest concentration of employment, $\mathrm{CBD}$ is expected to increase surrounding property values. However, investment on rail transit infrastructures and services at the $\mathrm{CBD}$ can reduce friction of distance and flatten the bid rent curve (Fejarang, 1994).

The impacts of light rail lines on regional economic development and nearby property values have been examined in various empirical studies for many American cities, including Bayonne (CaminsEsakov \& Vandegrift, 2018), Buffalo (Hess \& Almeida, 2007), Charlotte (Yan, Delmelle, \& Duncan, 2012), New York City (Lewis-Workman \& Brod, 1998), Norfolk (Wagner, Komarek, \& Martin, 2017), Dallas (Weinstein \& Clower, 1999), Houston (Pan \& Ma, 2009; Pan, 2013; Pan et al., 2014), Phoenix (Atkinson-Palombo 2010; Seo, Golub, \& Kuby, 2014), Los Angeles (Zhong \& Li, 2016), Portland (AlMosaind, Dueker, \& Strathman, 1993; Chen, Rufolo, \& Drucker, 1998; Knaap, Ding, \& Hopkins, 2001), San Jose, Sacramento, San Diego (Landis, Guhathakurta, \& Zhang,1994), and Seattle (Ransom, 2018), etc. Similar analyses have been carried out for cities in other countries, such as Montreal, Canada (Dubé et al., 2013; Dubé, Legros, Thériault, \& Des Rosiers, 2014), Queensland (Yen, Mulley, Shearer, $\&$ Burke, 2018) and Sydney (Mulley, Tsai, \& Ma, 2018) in Australia, and Singapore (Diao, Leonard, $\&$ Sing, 2017), etc.

There are also a number of studies investigating the impacts of heavy rail or commuter rail lines on population, employment, accessibility, and property values in many cities in U.S. and other countries, including San Francisco (Landis \& Loutzenheiser, 1995; Cervero \& Landis, 1997), Atlanta (Bollinger \& Ihlanfeldt, 1997; Bowes \& Ihlanfeldt, 2001), Boston (Diao, 2015), Washington D.C. (Green \& James, 1993), Miami (Gatzlaff \& Smith, 1993), Toronto (Haider \& Miller, 2000), Montreal (Dubé et al., 2013), Shanghai (Pan et al., 2014), Bangalore (Sharma \& Newman, 2018), and Xi'an (Li, 2018), etc. However, very few studies have focused on the impacts of rail transit in a non-zoning city.

Among the few studies investigating the effects of rail transit in a non-zoning city, Lee and Sener (2017) explored land-use development around light rail stations in the city of Houston between 2005 and 2014 using parcel level land-use data. This research focused on the impacts of light rail transit on land-use development. It showed that the most remarkable change of land development in the original light rail corridor was the increase of commercial land use between 2008 and 2014, following a small decline between 2005 and 2008. Industrial parcels had a similar pattern as commercial land use but changed at a smaller scale. Residential land uses had a modest increase. The gains in commercial, industrial and residential land uses came at the cost of decreasing vacant and other land uses.

Liu et al. (2018) analyzed the driving forces for the changes of employment subcenters by comparing Houston and Dallas, the former the largest US non-zoning city, and the latter, a zoning city of comparable size and similar regional situation. Neither Lee and Sener (2017) nor Liu et al. (2018) investigated the impacts of light rail on residential property values in their studies. 
There were also studies examining the impacts of zoning on residential property values. Some of them reported that the externalities of neighborhood land use traditionally controlled by zoning regulations have significant effects on market values of residential properties while the other studies found little evidence that non-residential land use creates systematic negative external effects on nearby residential properties and zoning significantly affects real estate prices (Jud, 1980).

Most relevant studies adopted the hedonic price model (HPM) introduced by Rosen (1974) to evaluate the effects of transit rail lines. For example, Gatzlaff and Smith (1993) utilized an HPM to investigate heavy rail in Miami, Florida; Chen et al. (1998) developed an HPM with GIS techniques to study the light rail in Portland, Oregon; Bowes and Ihlanfeldt (2001), Nelson (1992), and Nelson and McCleskey (1990) employed a simple HPM to examine MARTA in Atlanta, Georgia, etc.; Sharma and Newman (2018) adopted a traditional HPM to explore the uplift of apartment prices by the metro rail in Bangalore, India. Pan (2013) implemented an HPM to investigate the impacts of light rail in Houston, Texas.

Cross-sectional data have been widely employed to explore the impacts of rail transit. In a broad review by Higgins and Kanaroglou (2016) of 44 studies on light rail completed in North America over the past 40 years, the majority of the analyses, i.e., 32 studies, employed cross-sectional data that reveal the effects of LRT at one point of time. Only a smaller number of studies adopted longitudinal or repeat sales data.

The hedonic price model using cross-sectional data in the rail transit studies is likely yield biased results and often fails to explore causal relationships because their variables may not capture all the important characteristics of the station locations (Parmeter \& Pope, 2013; Diao, 2015). Dubé et al. (2013) pointed out that the omitted variable issues are far more difficult to be resolved in contrast to the spatial correlation problem. The difference-in-differences (DID) estimator was considered a simple way to avoid bias due to omitted variables.

The DID method has become popular in examining the effects of rail transit recently, such as the research on the effects of light rail transit on the residential real estate market in Hampton Roads, Virginia. Norfolk's Tide light rail (Wagner et al., 2017), the study of new services of seven light rail stations in Rainier Valley of Seattle, Washington (Ransom, 2018), the investigation of the housing value changes in treatment and control neighborhoods before and after the opening of a new mass rapid transit line in Singapore (Diao et al., 2017), and the identification of the increases of residential property value in the catchment areas following the delivery of the Light Rail Transit (LRT) system in the Gold Coast, Queensland, Australia (Yen et al., 2018).

Regardless of the methods and the data used to examine the impact of light rail, a majority of existing empirical studies found that rail stations have positive effects on nearby property values. These include Portland's light rail transit (LRT) by Chen et al. (1998) and Al-Mosaind et al. (1993), heavy rail in New York MTA and San Francisco BART by Lewis-Workman and Brod (1997), heavy rail in Toronto by Bajic (1983) and Haider and Miller (2000), commuter rail stations in Southern New Jersey and Suburban Philadelphia by Voith (1991, 1993), and commuter rail in Boston by Armstrong (1994). In a meta-analysis of the relevant literature, Debrezion et al. (2007) reported that commuter railway stations have a positive impact on the property value consistently higher than light and heavy railway/ Metro stations. It implied that rail transit can yield externalities and increase taxation base for local municipalities (Dubé et al., 2013).

A rail transit system may have mixed effects in terms of spatial locations or temporal phases because proximity to rail transit stations can impose nuisance effects like crime and noise to nearby neighborhood and land-use development affected by transit accessibility improvement needs time to become matured. Bowes and Ihlanfeldt (2001) found the heavy rail in Atlanta has large positive effects in high income neighborhood but negative effects in low income neighborhood, which contradicts the findings 
by Nelson and McCleskey (1990) and Nelson (1992). Gatzlaff and Smith (1993) also found slight positive effects of heavy rail in the high-income communities of Miami but insignificant effects in the lowincome communities. Similarly, Hess and Almeida (2007) found light rail in Buffalo has positive effects in high income station areas but negative effects in low income station areas. Landis (1994) reported light rail stations have positive effects on home prices in San Diego, negative effects in San Jose, and indiscernible effects in Sacramento. Yan et al. (2012) found that it was desirable living close to a station and housing prices began to have positive reactions to light rail after the rail system became operational. But proximity to the planned light rail corridor had negative impacts on housing prices before operations of the rail system commenced.

In addition to the individual studies, the meta analyses by Debrezion et al. (2007) and Mohammad, Graham, Melo, and Anderson (2013) also showed the variations among the empirical findings for rail transit impacts on property value. Based on a total of 57 observations obtained from the empirical studies, Debrezion et al. (2007) reported mixed results for the effects of rail stations on property value, ranging from a negative to an insignificant or a positive impact. Mohammad et al. (2013) synthesized the empirical results from 23 studies of 102 observations between 1991 and 2008 that estimated the impact of rail on land or property value changes. They found that land or property values have positive gains in close proximity to rail stations in most studies. The estimated effects had a large range, between $-45 \%$ to $100 \%$, while the average was $8 \%$ and the median was $5.4 \%$.

Most of the studies reviewed by Debrezion et al. (2007) and Mohammad et al. (2013) are hedonic models using cross-sectional data. Pan (2013) also had a summary of the results from the available empirical studies of rail transit impact on residential property values in North America before 2013. Some relevant studies in the U.S. and other countries after 2013 are listed in Table 3.

The recent empirical studies summarized in Table 3 also reported mixed results after controlling biases, spatial autocorrelation, spatial and temporal heterogeneity, and other factors using some newly developed methods. The research using the spatial Durbin and Geographically Weighted Regression (GWR) models by Zhong and Li (2016) reported that proximity to mature rail transit stations has positive effects on multi-family property values but negative effects on single-family properties in Los Angeles. The premium of transit access was also volatile for different development phases and rail technologies. The GWR models employed by Mulley et al. (2018) also showed that the effects of accessibility to light rail services in Sydney, Australia has significant spatial variation. The DID models utilized by Diao et al. (2017) revealed that the opening of the new rail line increased housing value in the neighborhoods located close to the new rail stations in Singapore. In contrast, the results from the DID models employed by Ransom (2018) suggested no significant value added by the light rail services to the residential neighborhoods in the Rainier Valley of Seattle, Washington. The DID models adopted by Wagner et al. (2017) reported even negative impacts of the constructed light rail line on property values in Norfolk, Virginia.

Debrezion et al. (2007) attributed the variations of the estimates to the nature of data, specific spatial characteristics, temporal effects, and methodology. Similarly, Mohammad et al. (2013) listed a number of factors that yield the significant variations, including the type of land use, rail service, and the impacted area, the maturity level of rail system, the proximity to stations, accessibility to roads, the geographical location, and the characteristics of methodologies, etc. Billings (2011) argued that the use of inadequate control groups may account for the large variation or the heterogeneity of the estimated effects.

In sum, a large number of the studies find significant positive effects of transit rail stations on residential housing values. But the positive effects are sometimes weak and vary with income, distance to local job centers, proximity to rail stations, and development phases, etc. There are also many studies that report negative, weak, or mixed impacts of rail stations on property values. The study on a non-zoning city may add to the literature more variety for the effects of light rail on residential property values. 
Table 3. Summary of recent studies for the impacts of transit rail lines on residential property values

\begin{tabular}{|c|c|c|c|c|c|}
\hline Study & Study Area & Transit Rail Type & Method & Data & $\begin{array}{l}\text { Effects of Transit Rail } \\
\text { Line on Residential Prop- } \\
\text { erty Value }\end{array}$ \\
\hline $\begin{array}{l}\text { Dubé et al. } \\
(2013)\end{array}$ & $\begin{array}{l}\text { Montreal, } \\
\text { Canada }\end{array}$ & Commuter Rail & $\begin{array}{l}\text { Hedonic price } \\
\text { equation using } \\
\text { the generalized } \\
\text { least squares } \\
\text { (GLS) approach } \\
\text { combined with } \\
\text { a difference-in- } \\
\text { differences (DID) } \\
\text { estimator }\end{array}$ & $\begin{array}{l}\text { A sample of repeat } \\
\text { sales between } 1992 \\
\text { and } 2009\end{array}$ & $\begin{array}{l}\text { Proximity to a commuter } \\
\text { train station translates } \\
\text { into a market premium } \\
\text { about } 11 \% \text { of mean hous- } \\
\text { ing price for properties } \\
\text { located in the immediate } \\
\text { vicinity of a station at } \\
\text { sufficient distance from } \\
\text { the CBD ( } 10 \mathrm{~km} \text { ) and } \\
\text { shades off at car driving } \\
\text { time to the closest station. } \\
\text { The overall market pre- } \\
\text { mium is } 2.6 \% \text { on mean } \\
\text { house price for the entire } \\
\text { region. }\end{array}$ \\
\hline Pan (2013) & $\begin{array}{l}\text { Houston, } \\
\text { Texas }\end{array}$ & Light rail & $\begin{array}{l}\text { Hedonic price } \\
\text { model (OLS) }\end{array}$ & $\begin{array}{l}\text { Home sales prices } \\
\text { from a property } \\
\text { transaction database } \\
\text { (InfoUSA) }\end{array}$ & $\begin{array}{l}\text { The opening of the light } \\
\text { rail has had significant net } \\
\text { positive } \\
\text { effects on residential } \\
\text { property values. But } \\
\text { immediate proximity to } \\
\text { light rail stations and } \\
\text { bus stops has significant } \\
\text { negative impacts on } \\
\text { properties } \\
\text { located within a quarter } \\
\text { mile of rail stops. }\end{array}$ \\
\hline $\begin{array}{l}\text { Zhang } \\
\text { and Wang } \\
\text { (2013) }\end{array}$ & Beijing, China & $\begin{array}{l}\text { Light Rail and } \\
\text { BRT }\end{array}$ & $\begin{array}{l}\text { Hedonic price } \\
\text { model (OLS), } \\
\text { spatial lag, and } \\
\text { error model }\end{array}$ & $\begin{array}{l}\text { Data sample drawn } \\
\text { from online sources } \\
\text { for the asking prices } \\
\text { of new housing } \\
\text { units }\end{array}$ & $\begin{array}{l}\text { Mass transit has signifi- } \\
\text { cantly positive effects on } \\
\text { land development and } \\
\text { transit proximity gener- } \\
\text { ated sizable price or value } \\
\text { premiums for the proper- } \\
\text { ties closeby. }\end{array}$ \\
\hline $\begin{array}{l}\text { Pan et al. } \\
(2014)\end{array}$ & $\begin{array}{l}\text { Houston, } \\
\text { Texas and } \\
\text { Shanghai, } \\
\text { China }\end{array}$ & $\begin{array}{l}\text { Light Rail and } \\
\text { Heavy Rail }\end{array}$ & $\begin{array}{l}\text { Hedonic price } \\
\text { model (OLS) and } \\
\text { multilevel regres- } \\
\text { sion model }\end{array}$ & $\begin{array}{l}\text { Home sales prices } \\
\text { from a property } \\
\text { transaction database } \\
\text { (InfoUSA) for } \\
\text { for Houston and } \\
\text { property transaction } \\
\text { data from local real } \\
\text { estate magazines in } \\
\text { Shanghai }\end{array}$ & $\begin{array}{l}\text { The results showed that } \\
\text { rail transit lines have } \\
\text { significantly positive } \\
\text { effects on residential } \\
\text { property values in both } \\
\text { Houston and Shanghai. } \\
\text { But notable variations of } \\
\text { rail transit effects were } \\
\text { observed at different } \\
\text { distance ranges and time } \\
\text { spans. }\end{array}$ \\
\hline $\begin{array}{l}\text { Seo et al. } \\
(2014)\end{array}$ & $\begin{array}{l}\text { Phoenix, } \\
\text { Arizona }\end{array}$ & $\begin{array}{l}\text { Light rail and } \\
\text { highway }\end{array}$ & $\begin{array}{l}\text { Spatial hedonic } \\
\text { price model with } \\
\text { combined spatial } \\
\text { lag and error } \\
\text { model using } \\
\text { generalized spatial } \\
\text { two-stage least- } \\
\text { squares (GS2SLS) } \\
\text { estimator }\end{array}$ & $\begin{array}{l}\text { The sales price } \\
\text { of single-family } \\
\text { detached } \\
\text { homes in } 2009 \\
\text { from the County } \\
\text { Assessor's } \\
\text { Office }\end{array}$ & $\begin{array}{l}\text { The accessibility benefits } \\
\text { adjacent to the station } \\
\text { or highway exit are } \\
\text { somewhat offset by the } \\
\text { disamenity associated with } \\
\text { close proximity, which } \\
\text { results in an inverted-U } \\
\text { pattern of the coefficients } \\
\text { of distance from both } \\
\text { light rail stations and } \\
\text { highway exits. }\end{array}$ \\
\hline
\end{tabular}




\begin{tabular}{|c|c|c|c|c|c|}
\hline $\begin{array}{l}\text { Zhong and } \\
\text { Li (2016) }\end{array}$ & $\begin{array}{l}\text { Los Angeles, } \\
\text { California }\end{array}$ & $\begin{array}{l}\text { Light rail and } \\
\text { heavy rail }\end{array}$ & $\begin{array}{l}\text { Spatial Durbin } \\
\text { models and } \\
\text { Geographically } \\
\text { Weighted } \\
\text { Regression models }\end{array}$ & $\begin{array}{l}\text { single-family } \\
\text { and multi-family } \\
\text { property sale } \\
\text { transactions }\end{array}$ & $\begin{array}{l}\text { Proximity to mature } \\
\text { rail transit stations } \\
\text { has positive effects on } \\
\text { multi-family property } \\
\text { values but negative } \\
\text { effects on single-family } \\
\text { properties. The premium } \\
\text { of transit access is volatile } \\
\text { in terms of different } \\
\text { development phases and } \\
\text { rail technologies. It is also } \\
\text { discounted by the Park- } \\
\text { and-Ride facilities near to } \\
\text { transit stations. }\end{array}$ \\
\hline $\begin{array}{l}\text { Wagner et } \\
\text { al. (2017) }\end{array}$ & $\begin{array}{l}\text { Norfolk, } \\
\text { Virginia }\end{array}$ & Light rail & $\begin{array}{l}\text { Difference- } \\
\text { indifferences } \\
\text { model (DID) }\end{array}$ & $\begin{array}{l}\text { sale price, sale-list } \\
\text { price spread and } \\
\text { time-on-market } \\
\text { data from a } \\
\text { multiple listing } \\
\text { service (MLS) }\end{array}$ & $\begin{array}{l}\text { Negative impacts of the } \\
\text { constructed light rail } \\
\text { line. Properties within } \\
1500 \text { meters experienced } \\
\text { a decline in sale price by } \\
\text { nearly } 8 \% \text {, while the sale- } \\
\text { list price spread decreased } \\
\text { by about } 2 \% \text {. }\end{array}$ \\
\hline $\begin{array}{l}\text { Camins- } \\
\text { Esakov and } \\
\text { Vandegrift } \\
(2018)\end{array}$ & $\begin{array}{l}\text { Bayonne, New } \\
\text { Jersey }\end{array}$ & Light Rail & $\begin{array}{l}\text { Hedonic price } \\
\text { model (OLS) } \\
\text { using annualized } \\
\text { price change as } \\
\text { the dependent } \\
\text { variable. }\end{array}$ & $\begin{array}{l}\text { repeat sales of } \\
\text { houses from an } \\
\text { Open Public } \\
\text { Records Search } \\
\text { System (OPRS) in } \\
2008 \text { and 2011 }\end{array}$ & $\begin{array}{l}\text { The new station has } \\
\text { no significant impacts } \\
\text { on annual house price } \\
\text { appreciation. }\end{array}$ \\
\hline $\begin{array}{l}\text { Ransom } \\
(2018)\end{array}$ & $\begin{array}{l}\text { Seattle, Wash- } \\
\text { ington }\end{array}$ & Light Rail & $\begin{array}{l}\text { Difference- } \\
\text { in-differences } \\
\text { regression } \\
\text { technique }\end{array}$ & $\begin{array}{l}\text { sales data from } \\
\text { the County } \\
\text { Department of } \\
\text { Assessments for } \\
\text { homes in the areas } \\
\text { around the light } \\
\text { rail stations serving } \\
\text { primarily residential } \\
\text { areas }\end{array}$ & $\begin{array}{l}\text { The results suggest that } \\
\text { light rail service did not } \\
\text { provide value to the } \\
\text { neighborhoods in the } \\
\text { Rainier Valley of Seattle, } \\
\text { Washington. }\end{array}$ \\
\hline $\begin{array}{l}\text { Yen et al. } \\
(2018)\end{array}$ & $\begin{array}{l}\text { Gold Coast, } \\
\text { Queensland, } \\
\text { Australia }\end{array}$ & Light Rail & $\begin{array}{l}\text { Difference-in- } \\
\text { Differences model }\end{array}$ & $\begin{array}{l}\text { Residential property } \\
\text { data - RP data } \\
\text { from a commercial } \\
\text { company } \\
\text { (CoreLogic) }\end{array}$ & $\begin{array}{l}\text { Property values started to } \\
\text { increase in the catchment } \\
\text { areas after announcement. } \\
\text { The highest increment } \\
\text { was found after solid } \\
\text { financial commitment } \\
\text { is made by government. } \\
\text { Property values then slow } \\
\text { during construction and } \\
\text { the operation period. }\end{array}$ \\
\hline $\begin{array}{l}\text { Mulley et al. } \\
(2018)\end{array}$ & $\begin{array}{l}\text { Sydney, } \\
\text { Australia }\end{array}$ & Light Rail & $\begin{array}{l}\text { Geographically } \\
\text { Weighted } \\
\text { Regression } \\
\text { (GWR) }\end{array}$ & $\begin{array}{l}\text { Residential prop- } \\
\text { erty data - RP data } \\
\text { from a commercial } \\
\text { company (Core- } \\
\text { Logic) }\end{array}$ & $\begin{array}{l}\text { Accessibility to light rail } \\
\text { services has significant } \\
\text { spatial variation. Light } \\
\text { rail has had more impact } \\
\text { outside the areas of the } \\
\text { city center. }\end{array}$ \\
\hline Diao (2015) & Boston & Heavy Rail & $\begin{array}{l}\text { Hedonic price } \\
\text { model, Heckman } \\
\text { selection model, } \\
\text { Heckman } \\
\text { selection model } \\
\text { with spatially } \\
\text { lagged dependent } \\
\text { variable, and } \\
\text { Heckman } \\
\text { selection model } \\
\text { with spatially } \\
\text { lagged error term }\end{array}$ & $\begin{array}{l}\text { The transaction and } \\
\text { stock data of single } \\
\text { family properties }\end{array}$ & $\begin{array}{l}\text { The subway system } \\
\text { exhibits substantial } \\
\text { potential for value capture } \\
\text { as measured by the overall } \\
\text { property value increase } \\
\text { in the impact zone. } \\
\text { However, the annual } \\
\text { revenue from value } \\
\text { capture is small compared } \\
\text { with the transit fare } \\
\text { revenue and the operating } \\
\text { deficit of the subway. }\end{array}$ \\
\hline
\end{tabular}




\begin{tabular}{|l|l|l|l|l|l|}
\hline $\begin{array}{l}\text { Diao et al. } \\
(2017)\end{array}$ & Singapore & $\begin{array}{l}\text { Heavy Rail and } \\
\text { Light Rail } \\
\text { in-Differences } \\
\text { model }\end{array}$ & $\begin{array}{l}\text { Spatial Difference } \\
\text { transaction data } \\
\text { from a real estate } \\
\text { ifformation system } \\
\text { ("Realis" database) }\end{array}$ & $\begin{array}{l}\text { Opening of the new rail } \\
\text { line increased housing } \\
\text { value in the neighbor- } \\
\text { hoods located within } \\
\text { the 600-metre network } \\
\text { distance from the new rail } \\
\text { stations by approximately } \\
\text { 8.6\%, The significant } \\
\text { "anticipation" effects were } \\
\text { found one year before the } \\
\text { opening of the rail line } \\
\text { but lessened approaching } \\
\text { to the opening date. }\end{array}$ \\
\hline $\begin{array}{l}\text { Sharma and } \\
\text { (2018) }\end{array}$ & $\begin{array}{l}\text { Bangalore, } \\
\text { India }\end{array}$ & Heavy Rail & $\begin{array}{l}\text { Hedonic price } \\
\text { model (OLS) }\end{array}$ & $\begin{array}{l}\text { Both panel data and } \\
\text { cross-sectional data } \\
\text { for apartments }\end{array}$ & $\begin{array}{l}\text { The results from the } \\
\text { model with panel data } \\
\text { showed significant land } \\
\text { value increases and a price } \\
\text { uplift of 4.5\% across the } \\
\text { whole city after the com- } \\
\text { mencement of the metro } \\
\text { rail operations. }\end{array}$ \\
\hline
\end{tabular}

\section{$3 \quad$ Methodology}

This research employs the traditional OLS model, the Multi-Level Regression (MLR) model, and spatial regression models to evaluate the impacts of transit rail lines on residential property values.

\subsection{OLS model and multi-level regression (MLR) model}

Pan and Ma (2009), Pan (2013), and Pan et al. (2014) described the general forms of the hedonic regression model, i.e., OLS estimation, and a standard two-level regression model with a set of variables representing the physical, neighborhood, and accessibility characteristics of properties for analyzing the effects of transit rail study on residential property values. They also addressed the advantages of MLR models over traditional OLS models based on the discussions in Chi and Voss (2005), Bryk and Raudenbush (1992), Raudenbush and Bryk (2002), and Hox (2002).

The multilevel regression model adopted in this study examines the effects of light rail on residential property values at two levels, i.e., the individual property level and the zonal level. The first level or individual property level variables include physical characteristics of homes, like size, age, access to rail stations, access to bus stops, distance to job centers, and a dummy variable about home transaction before or after the opening of the rail line. The second level or traffic analysis zone (TAZ) level variables include median income, population density, job density, job accessibility, and percentage of minority, etc.

\subsection{Spatial regression model}

The spatial dependence between observations is usually quantified by Moran's I (Moran, 1950) as follows,

$$
I=\frac{n}{\sum_{i=1}^{n} \sum_{j=1}^{n} w_{i j}} \frac{\sum_{i=1}^{n} \sum_{j=1}^{n} w_{i j}\left(x_{i}-\bar{x}\right)\left(x_{j}-\bar{x}\right)}{\sum_{i=1}^{n}\left(x_{i}-\bar{x}\right)^{2}}
$$


Where, $x_{i}$ are the interesting variables,

$\bar{x}$ is the mean of the variable $x_{i}$, $w_{i j}$ are the values of spatial weight matrix, $n$ is the number of observations, and $i, j$ are the index.

Two types of spatial regression models have been developed for different situations. The spatial lag model is utilized for the cases when dependent variables are spatially autocorrelated while the spatial error model is employed for the scenarios when the traditional regression model has a spatial residual pattern or spatially correlated errors. The formula of the spatial lag model (SLM), or the so-called spatial autoregressive model, is shown as follows,

$$
Y=X \beta+\rho W Y+\varepsilon
$$

Where, $Y$ is the $\mathrm{n} \times 1$ vector of a spatially lagged variable,

$X$ is the matrix of covariates of the independent variables,

$W$ is the $\mathrm{n} \times \mathrm{n}$ spatial weight matrix of the dependent variable,

$\rho$ is a spatial lag correlation parameter,

$\varepsilon$ is an $\mathrm{Nx} 1$ vector of error, i.e., $\mathrm{N}(0, \sigma 2)$.

In equation (2), $\rho W Y$ is the spatially lagged value for the dependent variable and is an independent error, which are decomposed from the error term of a standard OLS model that is correlated with the dependent variable.

And the spatial error model (SEM) is formulated as follows,

$$
\begin{aligned}
& Y=X \beta+\mu \\
& \mu=\lambda W \mu+\varepsilon
\end{aligned}
$$

Where, $\mu$ is a vector of autocorrelated disturbance,

$\lambda$ is a spatial error correlation parameter.

$Y, X, W$, and are the same as above.

These two models are utilized in a maximum likelihood estimation, which has been incorporated to the packages of R and GeoDa by Luc Anselin and his collaborators (Anselin, Syabri, \& Kho, 2006).

\section{$4 \quad$ Empirical study}

As the rail transit in a large non-zoning city, the Houston light rail transit (LRT) line, or so-called METRORail, opened to public in January 2004. It runs 7.5 miles with 16 stations along the line before 2014. The 7.5-mile METRORail, or the so-called Red Line, connects Texas Medical Center and and Downtown Houston, which are two largest regional employment centers with a large number of commercial-retail and office properties. The south end of the light rail line is Fannin South Park and Ride, located near to a sport arena, high-density apartment complexes, and recreation centers. The middle of the transit line is adjacent to Houston Zoo and Hermann Park, a large inner city recreation area.

Houston's METRORail transit line has been expanded in recent years. The 5.3-mile expansion of the original Red Line toward the Northside district was opened in December 2013. The new 3.3-mile Green line and 6.6-mile Purple line began services in May 2015. Two other LRT lines, i.e., the Uni- 
versity/Blue Line and the Uptown/Gold Line were proposed for development but halted due to lack of fund. To have an apples-to-apples comparison with the previous studies, this study focused on the original 7.5-mile Red Line.

The impacts of transit line on residential property values are examined using multiple analytical models, i.e., the traditional OLS model, the MLR model to handle spatial heterogeneous and spatial hierarchical data, and the spatial regression model to examine spatial dependence. The study area is defined as the TAZs intersecting with the METRORail stations in a quarter-mile, one-mile, two-mile, and three-mile radii. Pan (2013) and Pan et al. (2014) had figures to show the study area with the location of residential properties and rail stations, TAZ, and the alignment of the METRORail transit line and highways in the region.

\subsection{Data}

The residential property data were obtained from the InfosUSA's 2010 household database, which provides the physical characteristics and dollar values of residential properties, including sales price date on home sale, home size, home age, household income, mortgage loan amount, ethnicity, and contact for the household, etc. After removing redundant records, limiting transactions to ones after 1982 (the oldest year Houston CPI data is available from the Bureau of Labor Statistics), and selecting records with sales price information, the sample left 384,368 properties located in the Harris County with valid home size, age, and sales price between 1982 and 2010.

Home sales prices in different years are converted to comparable values using the Consumer Price Index (CPI) obtained from the Bureau of Labor Statistics. Figure 1 shows the unit sales prices of properties transacted between 1982 and 2010. It illustrates the sales prices for properties located in the Harris County region and those located in the corridor within 3 miles of rail stations.

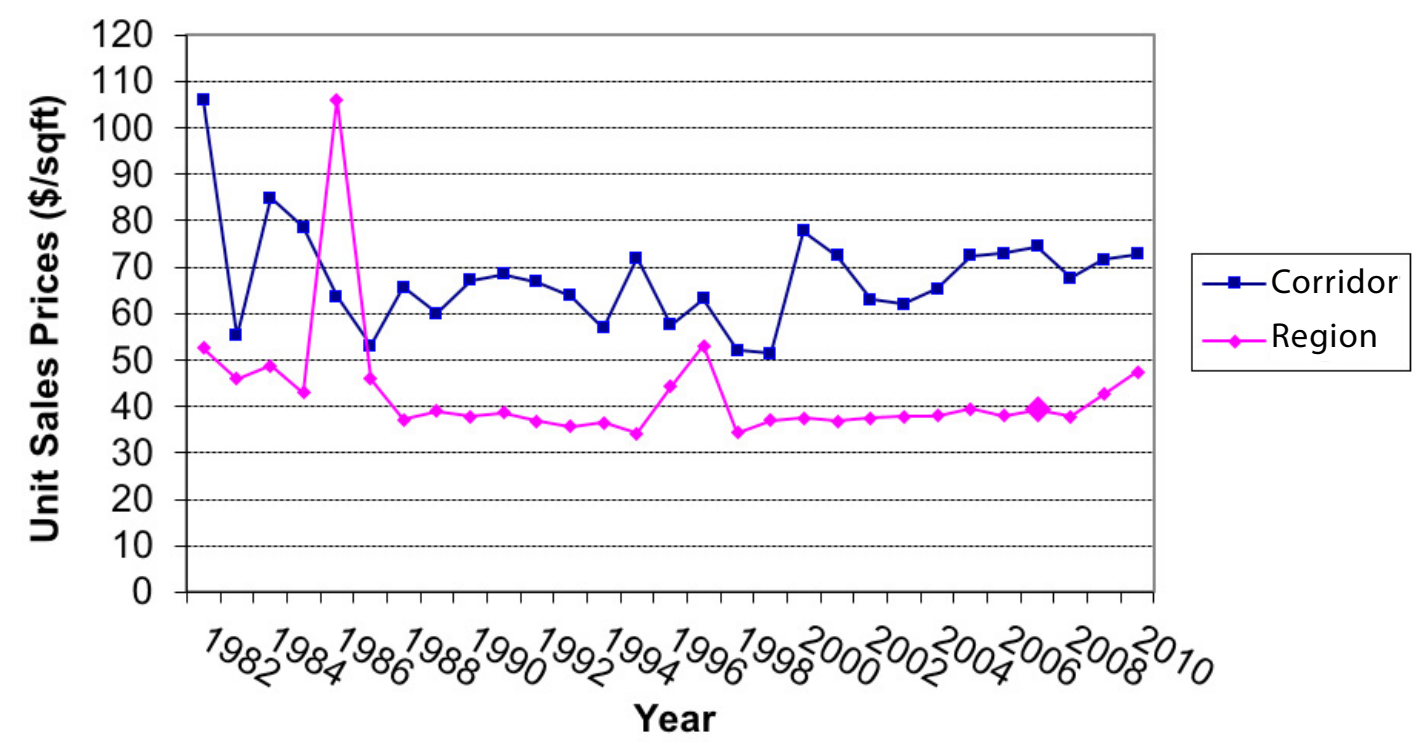

Figure 1. Unit home sales prices in the LRT corridor and the region, 1982-2010

Table 4 summarizes average home sales prices, home size, and home age at different distances to nearest light rail stations. It shows that the unit sales prices measured in dollar per square foot within the three-mile distance to the nearest light rail stations are almost twice as much as that of the rest in the 
county. The unit sales prices of properties within a quarter mile distance to light rail stations are about three times more than the regional average. The properties located less than a quarter mile distance to light rail stations has smaller size than the others while the properties located between a quarter mile and three-mile distance to light rail stations are about the same size as those located beyond three miles from the stations. It also shows that the properties along the light rail line are relatively older than the regional average.

Table 4. Home sales prices, home size, and home age at various distances to light rail stations

\begin{tabular}{|l|r|r|r|r|}
\hline Distance to Light Rail Stations & Number of Properties & Home Sales Prices $(\$ /$ sqft) & Home Size (sqft) & Home Age \\
\hline Less than1/4 Mile & 354 & 108.90 & 2,038 & 35 \\
\hline $1 / 4-1 / 2$ mile & 1,275 & 66.99 & 2,743 & 40 \\
\hline $1 / 2$ to 1 mile & 3,440 & 66.42 & 2,499 & 45 \\
\hline $1-2$ mile & 8,935 & 68.11 & 2,669 & 45 \\
\hline $2-3$ mile & 12,255 & 67.83 & 2,520 & 46 \\
\hline Within 3 miles & 26,259 & 68.15 & 2,572 & 45 \\
\hline Beyond 3 miles & 358,109 & 36.66 & 2,548 & 29 \\
\hline Regional Average & 384,368 & 38.83 & 2,550 & 30 \\
\hline
\end{tabular}

The variables employed in the OLS, the MLR, and the spatial regression models are listed in Table 5. The dependent variable is the logarithm of home sale prices in 2010. The explanatory variables are separated into two spatial levels for the MLR model. The variables at the first level include home structure attributes, such as home size and home age, a dummy variable for home sale before or after the opening of the light rail line, ${ }^{1}$ access to rail stations, access to bus stops, access to highway intersections, and access to employment centers. Access to rail stations is categorized into five groups measured by the distances to stations. Similarly, access to highway is categorized into four groups measured by the distance to highway intersections.

Access to bus stops is measured via a dummy variable, i.e., within one-quarter mile of a bus stop. Access to employment centers is measured as the logarithm of Euclidian distance from property location to the two regional job centers that are connected by the light rail, i.e., Downtown Houston and the Texas Medical Center.

The second-level explanatory variables are neighborhood characteristics and accessibilities at an aggregated zonal level, including median household incomes, population density, total job density, percentage of minority population, and total job accessibility. Job accessibility is measured using the general form of Hansen's (1959) accessibility measurement.

Most of empirical studies on the impact of rail transit on property values did not consider or discuss multicollinearity issues, perhaps based on the view that multicollinearity is not a problem with statistical techniques like OLS (Blanchard, 1987). The multicollinearity among spatial variables was addressed by Heikkila (1988). Bae et al. (2003) employed a generalized least square (GLS) model rather than OLS method to correct the problem while Hess and Almeida (2007) used the results of Pearson's correction coefficient values to eliminate multicollinearity. According to the tests on the explanatory variables listed in Table 5, collinearity only exists between the two distance variables to regional employment centers (Distcbd and Distmed). Due to the importance of both employment centers, both variables are kept for the model runs.

\footnotetext{
${ }^{1}$ Figure 1 shows home value trends for the Houston area as well for the corridor of the rail transit line. Corridor residences had experienced steady price appreciation in the years before and after the opening. This corroborates the idea that any effects of the dummy variable should not be ascribed to general area real estate market trends.
} 
Table 5. Variables used in the models

\begin{tabular}{|c|c|c|c|c|}
\hline Variables & Levels & & Descriptions & Source \\
\hline Dependent & \multirow{16}{*}{ 1st level } & Lgval 1000 & Log(Home Sale Prices $(\$ 1000))$ & InfoUSA \\
\hline \multirow{20}{*}{ Independent } & & Homesize & Home Size (square feet) & InfoUSA \\
\hline & & Homeage & Home Age (Year) & InfoUSA \\
\hline & & Raillineop & Home Sale Before (0) or After (1) METRORail Line Open & GIS Map \\
\hline & & RailQMI & Within one-quarter mile of METRO Rail stop & GIS Map \\
\hline & & RailHMI & Within one-quarter to one-half mile of METRO Rail stop & GIS Map \\
\hline & & Rail1MI & Within one-half to one mile of METRO Rail stop & GIS Map \\
\hline & & Rail2MI & Within one to two miles of METRO Rail stop & GIS Map \\
\hline & & Rail3Mi & Within two to three miles of METRO Rail stop & GIS Map \\
\hline & & BusStQMI & Within one-quarter mile of METRO Bus stop & GIS Map \\
\hline & & Hwyhmi & Within one-half mile of Highway intersections & GIS Map \\
\hline & & Hwylmi & Within one half to one mile of Highway intersections & GIS Map \\
\hline & & Hwy2mi & Within one to two miles of Highway intersections & GIS Map \\
\hline & & Hwy3mi & Within two to three miles of Highway intersections & GIS Map \\
\hline & & Distcbd & Distance to CBD & GIS Map \\
\hline & & Distmed & Distance to Medical Center & GIS Map \\
\hline & \multirow{5}{*}{ 2nd Level } & Medinc & Median Income $(\$ 1000)$ & CTPP/GIS Map \\
\hline & & Popdens & Population density & CTPP/GIS Map \\
\hline & & JobDens & Job density & CTPP/GIS Map \\
\hline & & Pctminor & Percentage of minority population & CTPP/GIS Map \\
\hline & & JobAcess & Total job accessibility & CTPP/GIS Map \\
\hline
\end{tabular}

\subsection{Analysis and results}

This study employs a large set of observations to examine the effects of light rail on property values. The MLR and OLS models are applied with 100 percent observations, which include 384,368 residential properties. To test the spatial autocorrelation in the OLS model, Moran's I method is applied to test the residuals of the residential property values in the OLS models. Spatial regression models including a spatial lag model and a spatial error model are utilized to examine the spatial dependence of the variables with 5 percent samples from the population.

Moran's I and spatial regression models in GeoDa or R's spdep package are utilized to examine spatial dependence of spatial variables. The outputs of Moran's I test are shown in Table 6 and plotted out in Figure 2.

Table 6. Spatial autocorrelation diagnostics for the OLS residuals of the residential property values.

\begin{tabular}{|l|l|}
\hline Moran's Index & $0.4227(0.0000)$ \\
\hline Moran's I statistic standard deviate & $18.4282(0.0000)$ \\
\hline Lagrange Multiplier (LM) Diagnostics for Spatial Lag (Spatial lag Model as alternative hypothesis) & $750.7199(0.0000)$ \\
\hline Lagrange Multiplier Diagnostics for Spatial Error (Spatial Error Model as alternative hypothesis) & $331.8029(0.0000)$ \\
\hline Robust Lagrange Multiplier to Spatial Lag & $529.23956(0.0000)$ \\
\hline Robust Lagrange Multiplier to Spatial Error & $110.3226(0.0000)$ \\
\hline
\end{tabular}




\section{Moran Scatterplot $\mathrm{I}=\mathbf{0 . 4 2 2 7}$}

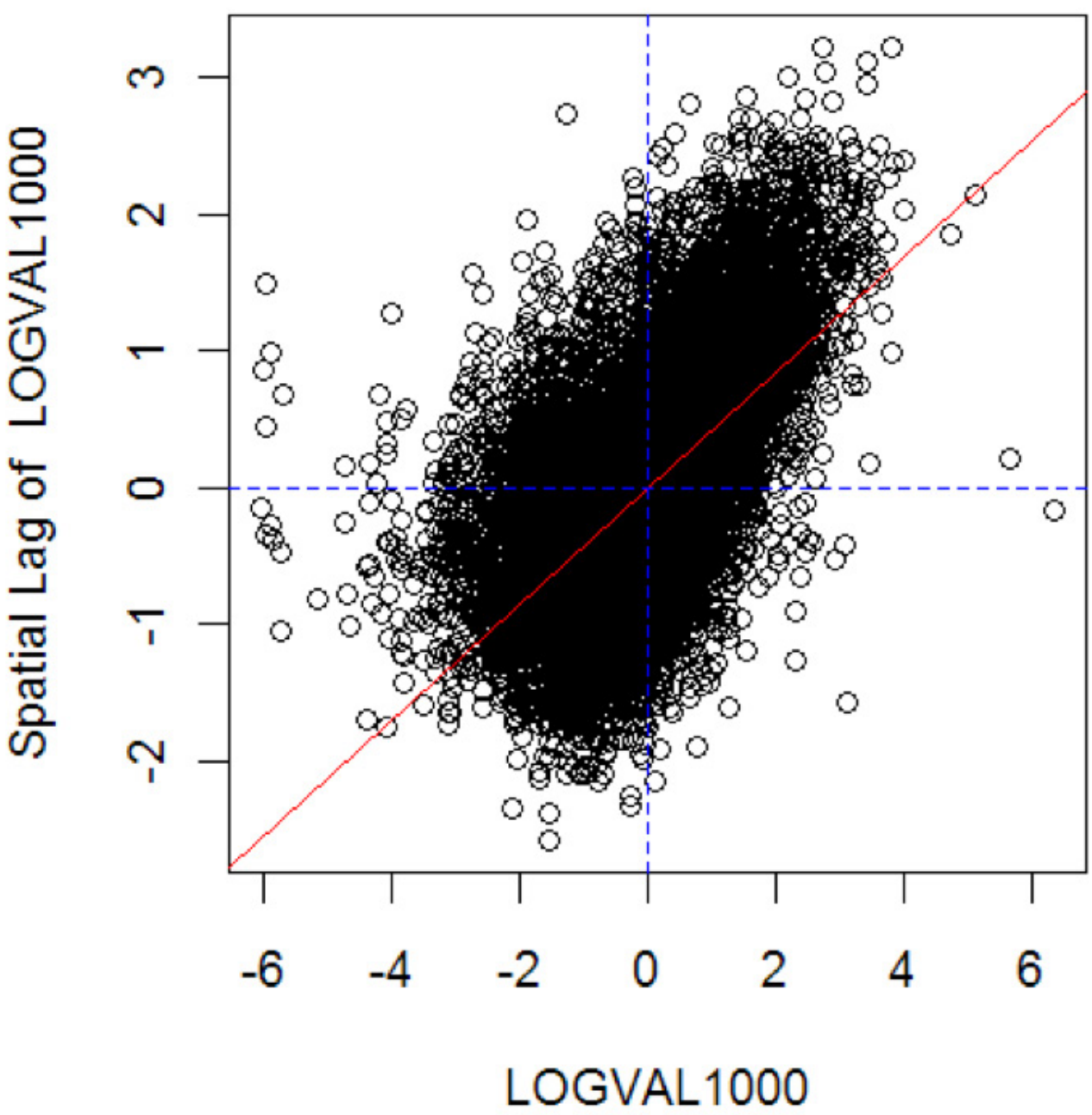

Figure 2. Moran scatter plot for the standardized logarithm of residential property values ( $\$ 1000)$

Table 6 shows the results of testing spatial autocorrelation in the OLS residuals. Moran's Index is calculated as the slope of the Moran scatter plot between standardized logarithm of residential property values and their spatial lag values (Figure 2). The score of 0.4227 is highly significant, which indicates significant spatial autocorrelation of the residuals in the OLS model. All the other testing results, including the Lagrange multiplier (LM) diagnostics for spatial lag and spatial error, and the robust Lagrange multiplier to spatial lag and spatial error, point to the rejection of the null hypothesis and indicate the presence of strong spatial autocorrelation in the OLS model. It also indicates the missing of lagged dependent variable and the existence of error dependence. So both spatial lag model and spatial error model need to be applied to examine the spatial dependence of the variables.

Table 7 reports the results of MLR and OLS with 100 percent of residential properties and 5 percent random samples of properties. It also shows the results of spatial regression models including spatial lag model and spatial error model with all the explanatory variables. 
Consistent with precursor empirical studies, Table 7 shows that the two physical characteristics of properties have significant impacts on residential property values. Home size (homesize) has significant positive effects while home age (homeage) has significant negative impacts.

Table 7 also reports that the opening of the light rail line (Raillineop) has significant positive effects on residential property values, which is consistent with the findings in the previous study by Pan and Ma (2009) and Pan (2013) and also in line with the results reported by Knaap, Ding, and Hopkins (2001) in Portland. All the models employed in this study consistently report that distances to rail station have significant positive effects on residential property values. The significant positive impacts exist within three-mile distance from rail stations, represented by five variables for rail station proximities (RailQMI, RailHMI, Rail1MI, Rail2MI, Rail3MI). To the contrary, the 2007 results in Pan (2013) reported that access to rail stations has negative impacts on the values of properties located within one-quarter mile of rail stops. The different effects of light rail access estimated using 2007 and 2010 InfoUSA's data may imply that Houston's METRORail has developed positive net effects on residential properties after sixyear services, which cannot be identified after a shorter time span, i.e., three years after the opening of the light rail line.

Pan (2013) also reported that access to bus stops has negative impacts on the values of properties located within one-quarter mile of bus stops. In Table 7, only the MLR model with 100 percent residential properties reports similar significantly negative effects of bus stops while all the other models report significantly positive effects of bus stops. The results imply that the introduction of light rail services to the corridor areas after a relatively long timespan has also changed the net effects of bus stops on residential property values.

The variables for access to highway intersections were not examined in the previous study by Pan and Ma (2009) and Pan (2013). The results in Table 7 show that highway has no significant effects on the residential properties located within a half mile distance from highway intersections. Only the spatial lag model reported that highway has significant positive impacts on properties located between a half mile and one-mile distance from intersections. All the models except MLR and spatial error model (SEM) with sampling data show that highway has significant positive effects on properties located between one- and two-mile distance from intersections. Only OLS model with 100 percent residential property data reports that highway has significant positive effects on properties between two- and threemile distance from intersections. It is clear that highway has positive effects on the values of residential properties at a certain distance from highway intersections, which is most notable between one- and two-mile distance.

Distances to the two largest employment centers, Downtown CBD and Texas Medical Center, connected by the light rail line are employed as two explanatory variables for the dimensions of location to the models. All the models confirm that Texas Medical Center has significant positive effects on property values while they all except the MLR with sampling data report that CBD has significant positive effects on residential property values, which is consistent with the urban economics theory with respect to higher property values in the areas closer to job centers (Anas, Arnott, \& Small, 1998).

The explanatory variables for neighborhood characteristics and accessibility measurement are found to have significant impacts on residential property values by almost all the models employed in this study. Median household income (Medinc) and total job density (JobDens) are reported to have significant positive effects while percentage of minority (Pctminor) is shown to have significant negative effects by all the models. Total job accessibility (Jobacess) is found to have significant positive effects by all the models except the MLR with sample data, Population density (PopDens) is reported to have significant negative effects by all the models except the MLR with 100 percent residential property data.

Table 7 shows that the combination of the variables representing physical, neighborhood, and accessibility characteristics of properties explains a fairly large percentage of variance of the natural log of property values, i.e., 43.60 percent reported by the OLS model and about 47.98 percent in the MLR 
model using the 100 percent residential property data, which are notably higher than the 37.62 percent in the OLS and the 40.52 percent in the MLR model reported by Pan and Ma (2009) and Pan (2013) using the 2007 InfoUSA's residential database with a similar set of variables.

Table 7 shows higher explanatory powers of the OLS and MLR models using the 5 percent random samples. The R-squared values of the OLS model increased slightly to 0.4447 and the Pseudo R-squared values of the MLR model increased to 0.5063 . The spatial error model (SEM) reports significantly positive effects of the spatially correlated errors, illustrated by the values of the coefficient parameter. In comparison to the OLS model, the SEM model improved the model fit with higher values of R-square and Log Likelihood (-17,056.9 vs. $-17,236.3)$ and a smaller value of Akaike info criterion (AIC) $(34,155.7$ vs. 34,514.6). Similarly, with an additional spatial lag indicator measuring the influence on the values of residential properties by their neighboring properties, the spatial lag model (SLM) reports a significant positive effect of the spatial lag indicator, which is illustrated by the values of the coefficient parameter. It also shows an improvement of model fit over the OLS model with higher values of R-square (0.4691) and Log Likelihood $(-16,889.8)$ and a smaller value of Akaike info criterion (AIC) $(33,823.6)$. Comparisons of R-square, Log Likelihood, and Akaike info criterion values all suggest that the spatial lag model performs better than the spatial error model.

Though both SLM and SEM models improve the model fit in the OLS models, their significant high values of the coefficients in the Breusch-Pagan tests suggest there is still serious heteroskedasticity in these two models. The likelihood ratio tests report significant high values in the coefficient in the spatial lag model (LRTLag) and the spatial error model (LRTErr), showing that spatial dependence still exists in the two models after the introduction of the spatial lag and spatial error components. 
Table 7. Comparison of results from MLR, OLS, SLM, and SEM

\begin{tabular}{|c|c|c|c|c|c|c|c|c|c|c|c|c|}
\hline \multirow{2}{*}{ Model } & \multicolumn{4}{|c|}{100 Percent of Properties } & \multicolumn{8}{|c|}{5 Percent Random Samples of Properties } \\
\hline & \multicolumn{2}{|c|}{ MLR } & \multicolumn{2}{|l|}{ OLS } & \multicolumn{2}{|l|}{ MLR } & \multicolumn{2}{|c|}{ OLS } & \multicolumn{2}{|c|}{ SLM } & \multicolumn{2}{|l|}{ SEM } \\
\hline \multirow{2}{*}{\multicolumn{13}{|c|}{$\begin{array}{l}\text { Fixed eff. } \\
\text { Level } 1\end{array}$}} \\
\hline & & & & & & & & & & & & \\
\hline Intercept & 3.2236 & $* * *$ & 3.8603 & $* * *$ & 3.9791 & $* * *$ & 3.9010 & $* * *$ & 2.9145 & $* * *$ & 10.8554 & $* * *$ \\
\hline homesize & 0.2331 & $* * *$ & 0.2877 & $* * *$ & 0.2480 & $* * *$ & 0.2830 & $* * *$ & 0.2474 & $* * *$ & 0.2619 & $* * *$ \\
\hline homeage & -0.0092 & $* * *$ & -0.0097 & $* * *$ & -0.0099 & $* * *$ & -0.0101 & $* * *$ & -0.0086 & $* * *$ & -0.0099 & *** \\
\hline Raillineop & 0.0350 & $* * *$ & 0.0398 & $* * *$ & 0.0301 & $* * *$ & 0.0375 & $* * *$ & 0.0380 & $* * *$ & 0.0353 & *** \\
\hline RailQMI & 0.4288 & $* * *$ & 0.3911 & $* * *$ & 0.6012 & $* * *$ & 0.4246 & $* *$ & 0.3593 & * & 0.4394 & $* *$ \\
\hline RailHMI & 0.2462 & $* * *$ & 0.3598 & $* * *$ & 0.5019 & $* * *$ & 0.4610 & $* * *$ & 0.3226 & $* * *$ & 0.4727 & *** \\
\hline Rail1MI & 0.2381 & $* * *$ & 0.3277 & $* * *$ & 0.3740 & $* * *$ & 0.3400 & $* * *$ & 0.2381 & $* * *$ & 0.3627 & $* * *$ \\
\hline Rail2MI & 0.1791 & $* * *$ & 0.3021 & $* * *$ & 0.2518 & $* * *$ & 0.2095 & $* * *$ & 0.1417 & $* * *$ & 0.2249 & $* * *$ \\
\hline Rail3Mi & 0.0884 & $* * *$ & 0.2121 & $* * *$ & 0.1668 & $* * *$ & 0.2175 & $* * *$ & 0.1502 & $* * *$ & 0.2155 & $* * *$ \\
\hline BusStQMI & -0.0146 & $* * *$ & 0.0945 & $* * *$ & 0.0416 & $* * *$ & 0.1131 & $* * *$ & 0.0859 & $* * *$ & 0.0935 & *** \\
\hline Hwyhmi & -0.0053 & & -0.0015 & & 0.0067 & & -0.0097 & & 0.0056 & & -0.0144 & \\
\hline Hwylmi & -0.0088 & & 0.0034 & & 0.0187 & & 0.0251 & & 0.0310 & * & 0.0139 & \\
\hline Hwy2mi & 0.0136 & $* *$ & 0.0129 & $* * *$ & 0.0293 & & 0.0219 & * & 0.0223 & * & 0.0164 & \\
\hline Hwy3mi & 0.0076 & & -0.0055 & $*$ & 0.0085 & & 0.0047 & & 0.0079 & & -0.0025 & \\
\hline Distcbd & 0.0075 & $* *$ & -0.0049 & $* *$ & -0.0071 & & -0.0070 & $* * *$ & -0.0087 & $* * *$ & -0.0062 & $*$ \\
\hline Distmed & -0.0267 & $* * *$ & -0.0192 & $* * *$ & -0.0188 & $* * *$ & -0.0171 & $* * *$ & -0.0112 & $* * *$ & -0.0183 & *** \\
\hline \multicolumn{13}{|l|}{ Level 2} \\
\hline Medinc & 0.0062 & $* * *$ & 0.0034 & $* * *$ & 0.0048 & $* * *$ & 0.0033 & $* * *$ & 0.0021 & $* * *$ & 0.0035 & $* * *$ \\
\hline Popdens & 0.0030 & * & -0.0071 & $* * *$ & -0.0042 & $*$ & -0.0064 & $* * *$ & -0.0034 & $* *$ & -0.0066 & $* * *$ \\
\hline Jobdens & 0.0026 & $* * *$ & 0.0034 & $* * *$ & 0.0026 & $* *$ & 0.0045 & $* * *$ & 0.0029 & $* * *$ & 0.0038 & *** \\
\hline Pctminor & -0.5325 & $* * *$ & -0.6479 & $* * *$ & -0.6615 & $* * *$ & -0.6687 & $* * *$ & -0.5012 & $* * *$ & -0.6629 & $* * *$ \\
\hline Jobacess & 0.0004 & $* * *$ & 0.0001 & $* * *$ & 0.0001 & & 0.0001 & $* * *$ & 0.0001 & $* * *$ & 0.0001 & $* * *$ \\
\hline \multicolumn{13}{|l|}{ Random eff. } \\
\hline \multicolumn{13}{|l|}{ Level 1} \\
\hline Intercept & 0.3393 & $* * *$ & & & 0.3256 & $* * *$ & & & & & & \\
\hline \multicolumn{13}{|l|}{ Level 2} \\
\hline Intercept & 0.0597 & $* * *$ & & & 0.0425 & $* * *$ & & & & & & \\
\hline$\rho$ (Eq. 6) & & & & & & & & 0.2420 & $* * *$ & & & \\
\hline$\lambda($ Eq. 8$)$ & & & & & & & & & & 0.2049 & $* * *$ & \\
\hline R Square & & & 0.4360 & & & & 0.4447 & & 0.4691 & & 0.4581 & \\
\hline Pseudo R Square & 0.4798 & & & & 0.5063 & & & & & & & \\
\hline Log Likelihood & & & & & & & $-17,236.3$ & & $-16,889.8$ & & $-17,056.9$ & \\
\hline AIC & & & & & $33,923.2$ & & $34,514.6$ & & $33,823.6$ & & $34,155.7$ & \\
\hline Breusch-Pagan Test & & & & & & & & & 863.4998 & $* * *$ & 914.6319 & *** \\
\hline LRTErr & & & & & & & & & & & 358.8515 & $* * *$ \\
\hline LRTLag & & & & & & & & & 692.989 & $* * *$ & & \\
\hline Obs. of Level 1 & 384368 & & 384368 & & 19072 & & 19072 & & 19072 & & 19072 & \\
\hline Obs. of Level 2 & 1427 & & & & 1207 & & & & 1207 & & & \\
\hline
\end{tabular}

Notes: ${ }^{*} \mathrm{p}=0.1$, significant at the 0.1 level, ${ }^{* *} \mathrm{p}=0.05$, significant at the 0.05 level, and ${ }^{* * *} \mathrm{p}=0.01$, significant at the 0.01 level. 


\section{$5 \quad$ Discussion and conclusions}

This research contributes to the growing literature on the relationship between light rail and residential property values in three unique respects, (1) it examines the effects of light rail on residential property values in the largest non-zoning city, i.e., Houston; (2) the effects of the Houston's light rail are examined by utilizing the 2010 residential property database, which allows the effects to be captured after a reasonable time span, i.e., six years after the opening of the new light rail line; (3) it employs spatial regression models together with the widely used ordinary linear regression (OLS) and the sophisticated multi-level regression (MLR) model to investigate the impacts of light rail system on residential property values.

In the largest non-zoning city, Houston's light rail is expected to have little, if any, effect on residential property values due to the decentralization of population, manufacturing, and office firms, low population density, and low transit mode share in the non-zoning city. However, this study shows that the opening of the light rail has significant positive effects on residential property values. It finds that Houston's METRORail has developed significant positive effects on the values of residential properties near to light rail stations after six-year services, which cannot be identified within a three-year time span in a study by Pan and Ma (2009) and Pan (2013). These results are consistent to the findings of Lee and Sener (2017) that reported a significant increase of commercial development along the original light rail corridor in Houston, about 4 to 10 years after its opening in 2004.

Policy makers and planners have considered light rail as a means to induce urban land-use change and increase land values due to the improvement of transit accessibility. However, the marginal increase in transit accessibility alone may not be large enough to change broad land-use patterns and thus raise land uses without government support (Giuliano, 1995, 2004; Cervero \& Landis, 1995). The empirical studies in the literature have reported mixed results and a large variation for the effects of rail stations on property value (Debrezion et al., 2007). It is argued that most studies on the impacts of light rail have done too early to find consistent patterns of land development and land value change. The few studies that analyze the effects of light rail over a large time span have shown LRT proximity has considerable influence on the probability of land-use change (Cervero \& Landis, 1997).

Our study confirms that it needs times for Houston's METRORail to develop significant positive effects on residential property values. Comparing to a zoning city, the time span for a non-zoning city to show significant change of land-use patterns and residential property values after the opening of light rail may be longer due to the lack of government assistance. The land-use study by Lee and Sener (2017) found that the spike of commercial and industrial land use in Houston's METRORail corridor between 2008 and 2014 after a small decline between 2005 and 2008. During the same periods, residential land uses had modest gains while the number of vacant and other land parcels decreased. It implies that the increased transit accessibility after the introduction of light rail has attracted businesses and firms to locate around the station areas, which increased the attraction of the neighborhoods and thus generated the value uplift for residential properties in the light rail corridor.

A limitation of this research lies in its modeling approaches. A major shortcoming of OLS and MLR is that they have not controlled spatial dependence (or spatial autocorrelation) and heterogeneity though MLR takes into account of the nesting structure of the spatial data. Though OLS and MLR models captured the effects of the light rail on residential property values, their results were considered biased and the capitalization effects of light rail were overestimated. Spatial regression models improve the model fit but they have not completely ruled out spatial autocorrelation. The difference-in-differences (DID) method provides a simple way to avoid the bias in the estimated coefficients that results from the omitted variables. It is also able to treat the problem of spatial autocorrelation among residuals if it is generated by omitted variables. We plan to adopt the DID method using longitudinal or repeat sales data in our future research. 
Our research is also limited to the original 7.5-mile Red Line. The recent expansion of Houston's METRORail provides us new opportunities to extend our study by comparing the effects of the original and new light rail lines. The current 22.7-mile light rail system covers a much larger and more diversified area. It would be interesting to explore the effects of the light rail on different communities.

Another limitation of this study is the lack of analysis on the temporal effects of the light rail. Though the two sets of data in 2007 and 2010 provide a general comparison of the light rail impacts in two different time spans, they are not enough to plot out the changes of effects at a yearly base. Our future study will fine tune the temporal difference of the light rail impacts.

Finally, this study is not a full-blown cost-benefit analysis. Policy conclusions about the desirability of light-rail require a wider scope than this study.

\section{Acknowledgements}

I am grateful to Peter Gordon at University of Southern California for helpful comments on earlier drafts. The opinions expressed in this paper are those of the authors alone.

Funding support was provided by the USDOT Tier 1 University Transportation Center Cooperative Mobility for Competitive Megaregions (CM2) (USDOT Award No. 69A3551747135) and Start-up Fund for High-Level Talents in Tongji University. 


\section{References}

Al-Mosaind, M. A., Dueker, K. J., \& Strathman, J. G. (1993). Light-rail transit stations and property values: A hedonic price approach, Transportation Research Record, 1400, 90-94.

American Public Transportation Association (APTA). (2011). APTA transit ridership report, first quarter, 2011. Retrieved from http://apta.com/resources/statistics/Documents/Ridership/2011_q1_ridership_APTA.pdf

Atkinson-Palombo, C. (2010). Comparing the capitalization benefits of light-rail transit and overlay zoning for single-family houses and condos by neighborhood type in metropolitan Phoenix, Arizona. Urban Studies, 47(11), 2409-2426.

Alonso, W. (1964). Location and land use. Cambridge: Harvard University Press.

Anas, A., Arnott, R., \& Small, K. A. (1998). Urban spatial structure. Journal of Economic Literature, 36(3), 1426-1464.

Anselin, L. (1988). Spatial econometrics: Methods and models. Boston: Kluwer Academic Publishers.

Anselin, L., Syabri, I., \& Kho, Y. (2006). GeoDa: An introduction to spatial data analysis. Geographical Analysis, 38(1), 5-22.

Armstrong, R. J. (1994). Impacts of commuter rail service as reflected in single-family residential property values. Transportation Research Record, 1466, 88-98.

Bae, C. C., Jun, M., \& Park, H. (2003). The impact of Seoul's subway Line 5 on residential property values. Transport Policy, 10, 85-95.

Bajic, V. (1983). The effects of a new subway line on housing prices in metropolitan Toronto. Urban Studies, 20, 147-158.

Bertaud, A. (2003). Clearing the air in Atlanta: Transit and smart growth or conventional economics. Journal of Urban Economics, 54, 379-400.

Bertaud, A. (2004). The spatial organization of cities: Deliberate outcomes or unforeseen consequence? Working paper. Berkeley, CA: University of California Berkeley, Institute of Urban and Regional Development. Retrieved from: http://escholarship.org/uc/item/5vb4w9wb.

Billings, S. B. (2011). Estimating the value of a new transit option. Regional Science and Urban Economics, 41(6), 525-536.

Blanchard, O. J. (1987). Comment. Journal of Business and Economic Statistics, 5, 449-451.

Bollinger, C. R., \& Ihlanfeldt, K. R. (1997). The impacts of rapid transit on economic development: The case of Atlanta's MARTA. Journal of Urban Economics, 42, 179-204.

Bowes, D. R., \& Ihlanfeldt, K.R. (2001). Identifying the impacts of rail transit stations on residential property values. Journal of Urban Economics, 50, 1-25.

Bryk, A. S., \& Raudenbush, S. W. (1992). Hierarchical linear models. Newbury Park, CA: Sage.

Camins-Esakov, I., \& Vandegrift, D. (2018). Impact of a light rail extension on residential property values. Research in Transportation Economics, 67, 11-18.

Central Houston Inc. (2009). Downtown Houston commute survey report. Retrieved from http://downtownhouston.org/site_media/uploads/attachments/2010-04-22/9A-2009_Downtown_Houston_ Commute_Survey_Report.pdf

Cervero, R., \& Landis, J. (1995). The transportation-land use connection still matters. Research report. Berkey, CA: University of California Transportation Center.

Cervero, R., \& Landis, J. (1997). Twenty years of the Bay Area rapid transit system: Land use and development impacts. Transportation Research A, 31(4), 309-333.

Chen, H., Rufolo, A., \& Drucker, K. (1998) Measuring the impact of light rail systems on single-family 
home values: A hedonic approach with geographic information system application. Transportation Research Record, 1617(98), 1250.

Chi, G., \& Voss, P. (2005) Migration decision-making: A hierarchical regression approach. Journal of Regional Analysis and Policy, 35(2), 11-22.

Debrezion, G., Pels, E., \& Rietveld, P. (2007). The impact of railway stations on residential and commercial property value: A meta-analysis. Journal of Real Estate Finance and Economic, 35, 161-180.

Diao, M. (2015). Selectivity, spatial autocorrelation, and the valuation of transit accessibility. Urban Studies, 52(1), 159-177.

Diao, M., Leonard, D., \& Sing, T. F. (2017). Spatial-difference-in-differences models for impact of new mass rapid transit line on private housing values. Regional Science and Urban Economics, 67, 64-77.

Dubé, J., Thériault, M., \& Des Rosiers, F. (2013). Commuter rail accessibility and house values: The case of the Montréal South Shore, Canada, 1992-2009. Transportation Research Part A, 54, 49-66.

Dubé, J., Legros, D., Thériault, M., \& Des Rosiers, F. (2014). A spatial difference-indifferences estimator to evaluate the effect of change in public mass transit systems on house prices. Transportation Research Part B, 64, 24-40.

Fejarang, R. A. (1994). Impact on property values: A study of the Los Angeles metro rail. Washington, DC: Transportation Research Board. (Preprint, Transportation Research Board, 73rd Annual Meeting, January 9-13).

Gatzlaff, D. H., \& Smith, M. T. (1993). The impact of the Miami Metrorail on the value of residences near station locations. Land Economics 69, 54-66.

Giuliano, G. (1995). The weakening transportation-land use connection. Research report. Berkeley, CA: University of California Transportation Center.

Giuliano, G. (2004). Land-use impacts of transportation investments: Highway and transit. In S. Hanson \& G. Giuliano (Eds.) The geography of urban transportation (pp. 237-273). New York: the Guilford Press.

Green, R. D., \& James, D. M. (1993). Rail transit station area development: Small area modeling in Washington, DC. Armonk, NY: M. E. Sharpe, Inc.

Haider, M., \& Miller, E. J. (2000). Effects of transportation infrastructure and location on residential real estate values: Application of spatial autoregressive techniques. Transportation Research Record, $1722,1-8$.

Hansen W. G. (1959). How accessibility shapes land-use. Journal of the American Institute of Planners, 25, 73-76

Heikkila, E. J. (1988). Multicollinearity in regression models with multiple distance measures. Journal of Regional Science, 28(3), 345-362.

Hess, D. B., \& Almeida, T. M. (2007). Impact of proximity to light rail rapid transit on station-area property values in Buffalo, New York. Urban Studies, 44(5/6), 1041-1068.

Higgins, C. D., \& Kanaroglou, P. S. (2016). Forty years of modelling rapid transit's land value uplift in North America: Moving beyond the tip of the iceberg. Transport Reviews. doi.10.1080/01441647. 2016.1174748

Hox, J. (2002). Multilevel analysis: Techniques and applications. Mahwah, NJ: Lawrence Erlbaum Associates.

Jud, G. D. (1980). The effects of zoning on single-family residential property values: Charlotte, North Carolina. Land Economics, 56(2), 142-154.

Knaap, G. J., Ding, C., \& Hopkins, L. D. (2001). Do plans matter? The effects of light rail plans on land values in station areas. Journal of Planning Education and Research, 21(1), 32-39.

Landis, J., Guhathakurta, S., \& Zhang, M. (1994). Capitalization of transit investments into single-family home prices. Working paper. Berkeley, CA: University of California Transportation Center. 
Landis, J., \& Loutzenheiser, D. (1995). Bart at 20: Bart access and office building performance. Working pager 648. Berkeley, CA: Institute of Urban and Regional Development University of California Berkeley.

Lee, R., \& Sener, I. N. (2017). The effect of light rail transit on land-use development in a city without zoning. Journal of Transport and Land Use, 10(1) 541-556.

Lewis-Workman, S., \& Brod, D. (1997). Measuring the neighborhood benefits of rail transit accessibility. Transportation Research Record, 1576, 147-153.

Li, Z. (2018) The impact of metro accessibility on residential property values: An empirical analysis. Research in Transportation Economics. doi.org/10.1016/j.retrec.2018.07.006

Liu, X., Pan, Q., King, L., \& Jin, Z. (2018). Analyzing the changes of employment subcenters: A comparison study of Houston and Dallas. Urban Studies. doi.org/10.1177/0042098018789554

McDonald J. F. (1995). Houston remains unzoned. Land Economics, 71(1), 137-140.

Mieszkowski, P., \& Mills, E. (1991). Analyzing urban decentralization: The case of Houston. Regional Science and Urban Economics, 21, 183-199.

Mills, E. S. (1967). An aggregate model of resource allocation in a metropolitan area. American Economic Review, 57, 197-210.

Mohammad, S., Graham, D., Melo, P., \& Anderson, R. (2013). A meta-analysis of the impact of rail projects on land and property values. Transportation Research Part A, 50, 158-170.

Moran, P. A. P. (1950). Notes on continuous stochastic phenomena. Biometrika, 37, 17-33.

Mulley, C., Tsai, C., \& Ma, L. (2018). Does residential property price benefit from light rail in Sydney? Research in Transportation Economics, 67, 3-10.

Muth, R. F. (1969). Cities and housing. Chicago: Chicago University Press.

Nelson, A. C. (1992). Effects of elevated heavy-rail transit stations on house prices with respect to neighborhood income. Transportation Research Record 1359, 127-132.

Nelson A. C., \& McCleskey, S. (1990). Improving the effects of elevated transit stations on neighborhoods. Transportation Research Record, 1266, 173-180.

Ottensmann, J. R. (1998). Market-based exchanges of rights within a system of performance zoning. Planning and Markets. Retrieved from http://www-pam.usc.edu

Pan, Q., \& Ma, L. (2009). The impacts of light rail on residential property values: A case study of the Houston METRORail transit line. Paper presented at the TRB 88th Annual Meeting, January 11-15, Washington, DC.

Pan, Q. (2013). The impacts of an urban light rail system on residential property values: A case study of the Houston METRORail transit line. Journal of Transportation Planning and Technology, 36(2), 145-169.

Pan, Q., Pan, H., Zhang, M., \& Zhong, B. (2014). The effects of rail transit on residential property values: A comparison 1 study on the rail transit lines in Houston and Shanghai. Transportation Research Record, 2453, 118-127.

Parmeter, C. F., \& Pope, J. C. (2013). Quasi-experiments and hedonic property value methods. In J. A. List \& M. K. Price (Eds.), Handbook on experimental economics and the environment (pp. 3-66). Cheltenham, UK: Edward Elgar Publishing.

Ransom, M. R. (2018) The effect of light rail transit service on nearby property values: Quasi-experimental evidence from Seattle. Journal of Transport and Land Use, 11(1), 387-404.

Raudenbush, S. W., \& Bryk, A. S. (2002), Hierarchical linear models, second edition. Thousand Oaks, CA.: Sage.

Rosen, S. (1974). Hedonic prices and implicit markets: Product differentiation in pure competition. Journal of Political Economy, 82, 34-55. 
Seigan, B. (1972). Land use without zoning. Lexington, MA: D.C. Heath.

Seo, K., Golub, A., \& Kuby, M. (2014). Combined impacts of highways and light rail transit on residential property values: A spatial hedonic price model for Phoenix, Arizona. Journal of Transport Geography, 41, 53-62.

Sharma, R., \& Newman, P. (2018). Does urban rail increase land value in emerging cities? Value uplift from Bangalore Metro. Transportation Research Part A, 117, 70-86.

Transportation Research Board (TRB). (1996). Transit and urban form, TCRP Report 16. Washington, DC: Transit Cooperative Research Program.

Voith, R. (1991). Transportation, sorting, and house values. AREUEA, 117(19), 117-137.

Voith, R. (1993). Changing capitalization of CBD-oriented transportation system: Evidence from Philadelphia, 1970-1988. Journal of Urban Economics, 33, 361-376. von Thunen, J. H. (1826). Der Isolierte Staat in Beziehung auf Landwirtschaft und Nationalokonomie. Hamburg: F. Perthes.

Wagner, G. A., Komarek, T., \& Martin, J. (2017). Is the light rail 'tide' lifting property values? Evidence from Hampton Roads, VA. Regional Science and Urban Economics, 65, 25-37.

Weinstein, B. L., \& Clower, T. L. (1999). The initial economic impacts of the DART LRT system. Denton, TX: University of North Texas, Center for Economic Development and Research.

Yan, S., Delmelle, E., \& Duncan, M. (2012). The impact of a new light rail system on single-family property values in Charlotte, North Carolina. Journal of Transport and Land Use, 5(2), 60-67.

Yen, B. T. H., Mulley, C., Shearer, H., \& Burke, M. (2018). Announcement, construction or delivery: When does value uplift occur for residential properties? Evidence from the Gold Coast light rail system in Australia. Land Use Policy, 73, 412-422.

Zhang, M., \& Wang, L. (2013). The impacts of mass transit on land development in China: The case of Beijing. Research in Transportation Economics, 40, 124-133.

Zhong, H., \& Li, W. (2016). Rail transit investment and property values: An old tale retold. Transport Policy, 51, 33-48. 